\title{
Prolegomenon
}

Verily, it is easier for a camel to pass through the eye of a needle than for a scientific man to pass through a door. And whether the door be a barn door or a church door, it might be wiser for him to consent to be an ordinary man and walk in the door rather than wait until all the difficulties involved in a scientific ingress are revealed. ${ }^{2}$

Humans use individualized viewpoints when they examine their worlds and when they share their ideas with others. A person without a worldview has no sense of the world and, thus, has no world. All genuine poets, authors, and artists are driven to present their unique and inner worlds to others. Audiences eagerly embrace creative people who openly and honestly share their worldviews in their works.

A personal worldview contains many perspectives and reactions to a variety of experiences. Some of these perspectives are inherited. Some are gained by learning. Some are attained by philosophical contemplation. As one's worldview develops, each individual must ask many questions and willingly discuss sociopolitical, moral, and cultural issues. An author, for example, needs to engage the reader in the events being described and in the viewpoints being exposed. When the author has woven philosophical contemplations with challenging, and often complex, socio-political, moral, and cultural issues, then the depth of the author's worldview emerges. As a result, the reader feels a more complete and a more satisfying understanding of the material the author has shared. The best author-reader relationship exists when the reader has an ongoing dialectic with the author.

However, an energetic dialectic between an author and a reader is not trouble-free. If the reader is searching for 'literary truth', then being in a dialectic with an author means that this type of reader will primarily focus on his or her disagreements with the author. That reader may perceive the author as a demagogue. On the other hand, if the reader uncritically conforms to whatever an author presents, then that reader is intellectually challenged. This type of reader feels completely unable, or is unwilling, to engage in an intellectual struggle with, or even to question, another's worldview.

An examination of these two approaches to reading another's differing worldview suggests the following. First, the reader who clings blindly to his or her worldview creates an intellectual tension whenever he or she reads an author who has a differing worldview. That reader wants to argue with the newly presented ideas. That reader wants the author to present some, if not all, opposing points 
of view. This type of reader, who appears to be very analytical, simply uses that posture to hide the reader's inability to give voice to an emotional reaction the reader has had while examining an author's unique worldview. His or her emotional excitement while reading another worldview cannot surface because its presence would mean that the reader would be perceived as someone who is unable to think critically. So, this kind of reader gets far too involved in the actual events being shared by an author to ever appreciate the aesthetic beauty of an author's differing worldview.

Second, the reader who refuses to argue with an author and simply conforms to the author's worldview does so because it's seen as being the 'politically correct' position to take. This type of reader is intellectually anemic. And being intellectually anemic, this type of reader doesn't possess the intellectual fortitude or strength to struggle with an opposing worldview. The 'political correctness' position taken by this type of reader is the first step that reader takes toward intellectual stagnation. An intellectually robust reader will adopt and employ better and more balanced approaches while examining an opposing worldview. For example, such readers can ask questions about the characters being presented and about the development of the story being shared. Readers can question how important the acts of any hero really are and then determine when, or if, a hero's quest in a story has become more spiritual. Readers can examine if any hero can truly belong to only one tradition. The boundaries of heroism can be debated. And then such talented readers can inquire about heroic virtues, analyze heroic responsibilities, and dissect the complex nature of good and evil.

As we examine the history of the Jews for the past two millennia, their survival is rooted in them being a most able group of people. Despite persecution and hardship, the Jews have familiarized themselves with their own history and have consistently examined their role in world history. In their religious beliefs, the Jews sought to affirm an intellectually robust and creative relationship for themselves with the rest of humanity and with their God.

Moral teachers, such as Confucius and Buddha, taught humanity that one's moral conduct is a reliable test and it is a fundamental religious precept. The prophets of Jewish tradition also emphasized the importance of moral conduct. Many of these prophets displayed great courage when they denounced their religious and political leaders in Judah and in ancient Israel. To accuse one's king of murder certainly calls that ruler's morality into question. Such bravery is seen in the question asked of king Ahab,

Hast thou killed and also taken possession? (1Kings 21:19.).

It's apparent, as well, in the statement directed at king David,

You are the man. (2Sam.12:7.). 
where the prophet is openly challenging the political leader's moral fiber and his political authority to rule because David has been such a hypocrite and he has lacked the righteousness needed to protect his people from evil. As we examine these and other statements in the Bible, we can ask ourselves: What is the origin of the moral courage first shown when the prophets confronted their leaders and then later was demonstrated by the actions of the people of Israel?

In Genesis 17:10 we read that God is the God of righteousness and justice. If these are God's highest values, then we realize that God will sustain these values. By accepting God as right and just, then believers need to see themselves as agents serving God in this world. As God's agents of righteousness and justice, then believers must have the capacity to distinguish 'good' from 'evil'. Since God is a moral entity, mankind cannot remain passively silent because humanity is part of this moral God's world. Humanity is, therefore, a representative of morality and justice in this world.

In its appeals, humanity can entreat from God and to God. In the religious and philosophical poem of Ibn Gabirol (1021-1058), the Keter Malkhut, which is recited annually on Yom Kippur, the Day of Atonement, he stated,

If I cannot hope for your mercy,

who but you could protect me?

Therefore, though you would slay me,

I hope and trust.

And were you to see my impiety

I would flee from you to Thee.

I would hide from your wrath in your shadow.

I'll hold to the edge of your mercy

until you have mercy-

And not allow you to go away,

not until you've blessed me. ${ }^{3}$

Even an angry rebel who is a believer doesn't turn away from God. In postBiblical literature we find other statements about God's anger and about God's mercy, such as:

The Rabbis say: God may be likened to a king who had twelve sons of whom two died. He began to console himself with the ten. Two more died and he began to console himself with the eight. Two more died and he began to console himself with the six. Two more died and he began to console himself with the four. Two more died and he began to console himself with the two. When they had all died, he began to lament over them, 'How sitteth solitary?" 
The two prophets, Abraham and Moses, acting as God's agents were each able to draw near to God and also to dispute with God. Abraham is more universal than Moses when he spoke in defense of the people of Sodom and Gomorrah before God destroyed those two cities. In the post-Biblical literature, Abraham also appears to confront God and to silence the Torah for having testified to God against the people. Moses sought God's mercy in spite of his people's transgressions against God. Other agents of God, such as Rachel, confront God. Jeremiah shares that when Rachel was trying to awaken God's mercy, she presented her compassion to God in direct contrast to God's zealousness.

Elijah also challenges God,

And he cried unto the Lord and said, 'Oh, Lord, my God, hast Thou also brought evil upon the widow with whom I sojourn by slaying her son?' (1Kings 17:20.).

Among the difficulties any historian faces when presenting conclusions and interpretations of past events are those conclusions and interpretations that are seen as being ones that are reflecting on the future. The old notion that history is 'everyone's teacher' was based on accepting humans as historical entities. Today's historians are creating conclusions and interpretations based on references to narrower socio-political ideologies. That means that today's historians are using a very subjective framework in their research and writings and they are presenting readers with a very different historical perspective.

Historians face other obstacles whenever they examine religion or religious ideology. Here, historians need to pay particular attention to some fundamental tendencies that are present in some religious sects. Historians and any literary critique focused on exploring the texts of religious sects must make the reader aware of the historical changes within those sects. The historical interpretations given to these diverse texts must also contain both the ideology of the followers, as well as the followers' fundamental values and religious rituals. Caution is needed since two different fluxes are in contradiction. On the one hand, we can examine the holiness of the rituals, but, on the other hand, we must realize that within most religions human actions are seen as God's outcomes and, as such, human actions are seen within each religion as having no identified historical timeframe. Historical and religious material discourse is complex for both historians and their readers, especially as both employ cultural theories in their historical and literary analyses.

For Biblical scholars, the challenges they face are even greater than those faced by other historians. For example, today's Biblical historians must take into consideration the historical time frame that cannot always be employed in their analyses. The Biblical historians also face unique challenges rooted in the ancient 
languages of their texts. Additionally burdensome are the often hidden sociopolitical and economic issues of ancient times that must also be factored into their interpretations and conclusions.

In some cases, Biblical historians are assisted by the discoveries made by archeologists excavating ancient sites in the Middle East.Another possible source of assistance for Biblical historians can be found in the literature of the Near East. Yet the ever-present dangers previously discussed, those of the religious domain and those of socio-political interpretations, still face the Biblical historian who examines the ancient literature of the Near East. Those scholars utilizing ancient Jewish literature must place the narratives being examined in a much larger context to demonstrate that very powerful connections existed between the ancient people of Israel and other cultures and religions being practiced in neighboring states.

Examining the socio-political context of the Near East in the $9^{\text {th }}$ century, we discover that in the year 853 that Shalmaneser, The Third, (858-824 B.C.E.) began his military campaigns in the north and in the south. His motives for these campaigns were purely economical, since his primary motive was to gain control of the important trade routes in that region. Against the threat of Shalmaneser's massive invasions, the three following regional rulers formed an opposing military coalition: Ben Hadad, the king of Damascus, along with the king of Hamath, and including Ahab, the king of Israel. The armies of these three countries battled Shalmaneser in 853 B.C.E. in Qarqar (Karkar). In this battle Ahab, king of Israel, brought not only his army to this encounter, but he also brought his famed chariots onto that battlefield. During his reign, Shalmaneser fought this military coalition a few more times following their first military encounter in 853 B.C.E. Only in 841 B.C.E. could Shalmaneser claim victory against the coalition nations that had been opposing him. In the last six years of his reign, following his battles with the coalition nations, Shalmaneser faced increasing turmoil at home and he lost the territories he had claimed in his earlier military victories.

In Elijah's narratives he reports that king Ahab was killed in the battle of Ramoth-Gilead in 852 B.C.E., and that his son, Ahaziah, continued the Omri dynasty. A year later, in 853 B.C.E., with Ahaziah's accidental death, his brother, Jehoram, succeeded him as king. In this political context, Moab rebelled against Israel and a serious revolt broke out in 842 B.C.E. General Jehu led that revolt in ancient Israel. The prophet Elisha, who had been the disciple of the prophet Elijah, supported General Jehu. The dynasty of Omri in ancient Israel, which had lasted forty years, was destroyed by this revolt.

It is the task of the prophet to listen to the voice of God. This 'voice' came to the people in the form of rain, which appeared right after Elijah's successful defeat and encounter with the prophets of Ba'al (18:45). Here the voice of God 
appears as rain representing and proclaiming God's forgiveness and God's acceptance of the people's repentance. According to the Biblical text, God had caused the drought in Israel because of the Israelites' inclusion of the foreign and forbidden cult of Ba'al within their religious tradition. And although the Biblical storyteller in the narratives of Elijah emphasizes the greatness of $Y H W H$, Josephus presents a different tradition in his work on this episode in Elijah's narrative. Scholars accept Josephus' work as a reliable source, as can be seen in the following,

Now Menander mentions this drought in his account of the acts of Ethbaal, King of the Tyrians, where he says thus: 'Under him there was a want of rain from the month Hyperberetaeus till the month of Hyperberetaeus of the year following. But when he made supplication, there came great thunders'. (Ant. 8.8.2.).

The task in this work is quite complicated, not only because of the different sources presented by these three religious traditions, but also because within each of these three traditions sources exist which sometimes contradict one another. Also, some of these sources were allowed to be more imaginative in their development than the original story itself. The narratives of Elijah found in Judaism, Christianity, and Islam, and in the literature of that ancient time, will be examined in this study in the light of the events presented by these three traditions. The three most important questions that this work will endeavor to answer are:

- Why is Elijah such a revered character in the Jewish, Islamic, and Christian traditions?

- Why did Elijah become a favorite hero who overshadowed the Biblical story of the murdering of 450 prophets of $\mathrm{Ba}$ al, along with the killing of one hundred soldiers?

— When did the stories depicting Elijah as a favorite hero first appear?

The third question listed above may prove to be the most difficult one to answer.

\section{Endnotes-Preface and Prolegemenon}

1 Buber, Martin, Tales of the Hasidim: The Later Masters, Olga Marx (tr.), Schocken Books, New York (1961), 214.

2 Arthur, Stanley Eddington, The Nature of the Physical World, New York (1919), 342.

3 Selected Poems of Soloman Ibn Gabriol, Peter Cole (tr.), Princeton University Press (2001), 188.

4 Lam. Rab. Prom. 